\title{
Journal of

\section{Detailed Biological Profiling of a Photoactivated and Apoptosis Inducing pdppz Ruthenium(II) Polypyridyl Complex in Cancer Cells}

\author{
Suzanne M. Cloonan, ${ }^{\dagger, \|, \Delta}$ Robert B. P. Elmes, ${ }^{\ddagger}, \|, \Psi$ MariaLuisa Erby, ${ }^{\dagger}$ Sandra A. Bright, ${ }^{\dagger}$ \\ Fergus E. Poynton, ${ }^{\ddagger}$ Derek E. Nolan, ${ }^{\dagger}$ Susan J. Quinn, ${ }^{\S}$ Thorfinnur Gunnlaugsson, ${ }^{*}{ }^{\ddagger}$ \\ and D. Clive Williams* ${ }^{\dagger}$ \\ ${ }^{\dagger}$ School of Biochemistry and Immunology and Trinity Biomedical Sciences Institute, Trinity College Dublin, Dublin 2, Ireland \\ ${ }^{*}$ School of Chemistry and Trinity Biomedical Sciences Institute, Centre for Synthesis and Chemical Biology, Trinity College Dublin, \\ Dublin 2, Ireland \\ ${ }^{\S}$ School of Chemistry and Chemical Biology, University College Dublin, Dublin 2, Ireland
}

Supporting Information

\begin{abstract}
Ruthenium polypyridyl complexes show great promise as new photodynamic therapy (PDT) agents. However, a lack of detailed understanding of their mode of action in cells poses a challenge to their development. We have designed a new $\mathrm{Ru}(\mathrm{II}) \mathrm{PDT}$ candidate that efficiently enters cells by incorporation of the lipophilic aromatic pdppz ([2,3$h]$ dipyrido[3,2-a:2',3'-c]phenazine) ligand and exhibits photoactivity through incorporation of 1,4,5,8-tetraazaphenanthrene ancillary ligands. Its photoreactivity toward biomolecules was studied in vitro, where light activation caused DNA cleavage. Cellular internalization occurred via an energy dependent mechanism. Confocal and transmission electron microscopy revealed that the complex localizes in various organelles, including the mitochondria. The complex is nontoxic in the dark, with cellular clearance within $96 \mathrm{~h}$; however, upon visible light activation it induces caspasedependent and reactive-oxygen-species-dependent apoptosis, with low micromolar $\mathrm{IC}_{50}$ values. This investigation greatly increases our understanding of such systems in cellulo, aiding development and realization of their application in cancer therapy.
\end{abstract}

\section{INTRODUCTION}

The excellent photophysical properties of $\mathrm{Ru}(\mathrm{II})$ polypyridyl complexes have been intensely investigated over the past 30 years with a view to varied applications. ${ }^{1}$ The biological activity of $\mathrm{Ru}$ (II) complexes has been investigated since the early 1950 s when Dwyer and co-workers reported their antibacterial activity. Since then a number of complexes have been developed as potential anticancer agents. ${ }^{2-4}$ In particular, their DNA binding affinity and phototriggered DNA damage have presented them as potential cellular imaging and therapeutic agents. ${ }^{5-12}$ The advantages of using such $\mathrm{Ru}(\mathrm{II})$ polypyridyl complexes as cellular targeting agents lies in the fact that the structural nature of the polypyridyl units will dictate the overall function of the metal complex, which includes their solubility, lipophilicity, charge, and importantly, their photophysical properties. The use of extended polypyridyl ligands suchs as dipyrido[3,2-a:2', $\left.3^{\prime}-c\right]$ phenazine (dppz) allows strong binding to DNA through intercalation. ${ }^{4}$ The $[\mathrm{Ru}-$ $\left.(\text { phen })_{2} \mathrm{dppz}\right]^{2+}($ phen $=1,10$-phenanthroline $)$ acts as a lightswitch complex, which is nonluminescent in solution but luminesces strongly when bound to DNA which can be applied to DNA imaging. Recently, $\mathrm{Ru}(\mathrm{II})$ complexes developed by us and others ${ }^{13,14}$ have been shown to act as effective cellular imaging agents without giving rise to cellular photodamage. Kelly et al., have shown that $\left[\mathrm{Ru}(\mathrm{TAP})_{2} \mathrm{dppz}\right]^{2+}(\mathrm{TAP}=$ tetraazaphenanthrene), which contains $\pi$-deficient, electron accepting ligands, causes photodamage of DNA through oxidation of guanine. ${ }^{15-17}$ The related complex [Ru$\left.(\mathrm{TAP})_{2} \mathrm{bpy}\right]^{2+}$ has been shown to cause DNA damage through photoadduct formation. ${ }^{30}$ Recently, crystallographic resolution of enantiopure $\mathrm{Ru}(\mathrm{II})(\mathrm{dppz})$ complexes bound to DNA sequences has been achieved by Kelly, Cardin, and coworkers ${ }^{5,11}$ and Barton ${ }^{18}$ and co-workers. These structures have provided detailed structural understanding of the binding interactions that give rise to the light-switch and photodamage phenomena.

Photodynamic therapy (PDT) is a well-recognized tumor ablative modality for the efficacious treatment of various cutaneous and deep tissue tumors. ${ }^{19}$ PDT involves the administration of a "photosensitizer" either systemically or locally and subsequent illumination with a low energy, tissuepenetrable light. The interaction of the photosensitizer and light results in the photochemical activation of molecules within

Received: December 8, 2014

Published: May 11, 2015 
a<smiles>CC#CC1c2ncccc2C(=O)C(=O)c2cccnc21</smiles>

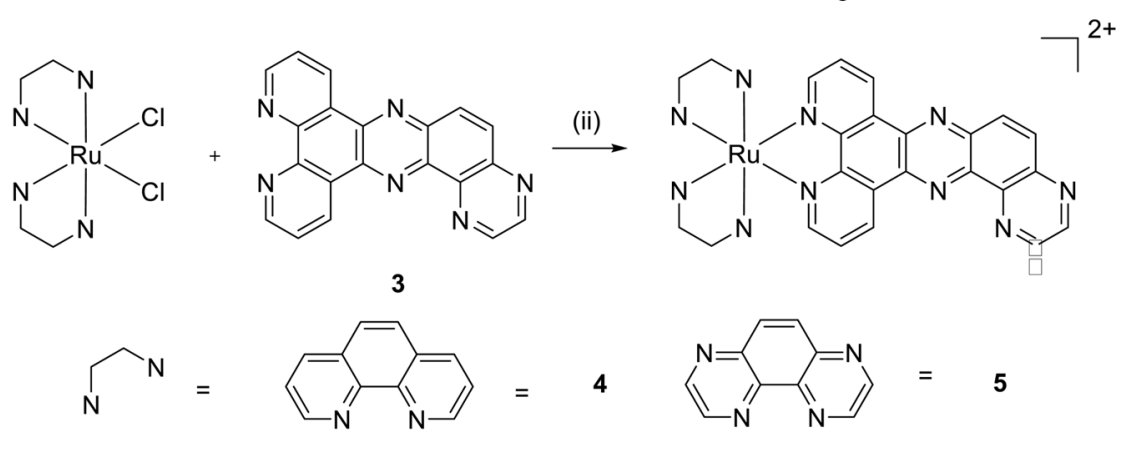

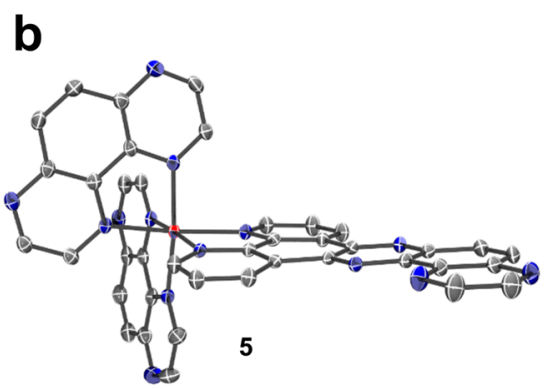

C

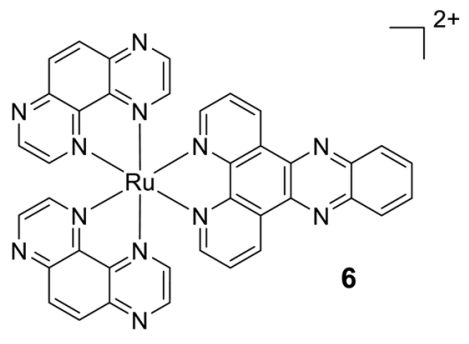

Figure 1. (a) Synthesis of 3 (free ligand) and corresponding Ru(II) complexes 4 and 5: (i) glyoxal, EtOH, reflux; (ii) $\mathrm{H}_{2} \mathrm{O}, 50$ W. (b) X-ray crystal structure of $5 . \mathrm{PF}_{6}{ }^{-}$counterions and solvent molecules are omitted for clarity (see Supporting Information for full structure), and ellipsoids are shown at $40 \%$ probability. (c) Chemical structure of 6.

the cell (usually the production of activated oxygen species) which results in its rapid destruction. The ideal photosensitizer should be water-soluble, easily accumulate in a cancer cell, possess no or very low dark toxicity, and be nonmutagenic. ${ }^{20}$ Importantly, it should be readily available and be able to induce programmed cell death. A majority of PDT agents developed to date have been porphyrin-based and as a result suffer from a number of undesirable characteristics: hydrophobicity, poor light absorption, lack of specificity, dark toxicity, and prolonged skin sensitivity, to name but a few. ${ }^{21} \mathrm{Ru}(\mathrm{II})$ polypyridyl complexes have recently been recognized as a major class of "new" types of PDT agents that can overcome some of the above problems. ${ }^{22,23}$ While such systems often possess higher energy absorptions than that seen for porphyrin-based systems, these can often been "pushed" to longer wavelengths by ligand design or by using two-photon excitation, the latter enabling the addressing of the excited state properties of the complexes at comparable or longer wavelengths than currently used in the clinic.

Interestingly, while a number of $\mathrm{Ru}(\mathrm{II})$ based complexes have been shown to successfully induce DNA photocleavage following light activation in vitro, ${ }^{2,7,22,23}$ only a limited number of such complexes have shown promise as potential PDT agents by demonstrating photoactivation induced cytotoxicity at a cellular level, ${ }^{3,12,24}$ while there has only been one report to date into the biological mechanism of action of cell death behind such $\mathrm{Ru}(\mathrm{II})$ polypyridyl complex-induced PDT within cells. $^{25}$ It is clear that in order to realize the therapeutic and diagnostic potential of these complexes, a thorough understanding of the internalization properties and activity is essential. Ideally, this requires mapping the path from uptake to localization to activity and toxicity and finally the means and extent of clearance, and while a number of studies have explored individual aspects, a full picture has yet to be captured. Thomas and co-workers have demonstrated that various $\mathrm{Ru}$ (II) polypyridyl complexes can be taken up into cells by nonendocytotic active transport. Using noncytotoxic $\mathrm{Ru}(\mathrm{II})$ complexes, the group showed that such complexes could accumulate within cells and directly image nuclear DNA. ${ }^{26}$ Indeed, a dinuclear $\mathrm{Ru}(\mathrm{II})$ polypyridyl compound was found to enter living cells, accumulated in the nucleus (and other organelles), and could directly image nuclear DNA utilizing the MLCT "light-switch" property of the compound. Several other researchers have shown similar effects, but often the delivery of such complexes has required the use of structures possessing polyamino acid conjugates as delivery vehicles. ${ }^{27-30}$

In this study we report a comprehensive profile of the biological activity of a new $\mathrm{Ru}(\mathrm{II})$ polypryridyl anticancer phototherapy agent, $\left[\mathrm{Ru}(\mathrm{TAP})_{2} \mathrm{pdppz}\right]^{2+}(\mathrm{pdppz}=[2,3-$ $h]$ dipyrido $\left[3,2-a: 2^{\prime}, 3^{\prime}-c\right]$ phenazine) 5. The key design features of this complex are the combination of (a) an extended "hooked" dipyridophenazine ligand for enhanced intercalation and DNA binding with (b) a $\pi$-deficient ligand network for phototriggered damage. In addition, we present results for the control complex $\left[\mathrm{Ru}(\mathrm{phen})_{2} \mathrm{pdppz}\right]^{2+} \mathbf{4}$ which also possesses the "hooked" dipyridophenazine ligand but is not expected to 
cause significant photodamage due to the absence of the TAP ligands. Rapid cellular uptake of these complexes followed by localization within mitochondria is observed. This is followed by perinuclear clustering of the mitochondria, which results in changes in cellular appearance with the formation of a concave or bean-shaped nucleus. $\mathbf{5}$ is found to give rise to minimal dark toxicity and recovery of the cell upon removal and elimination of the complex. Then, upon photoactivation, programmed cellular death is turned on leading to rapid cellular death. Furthermore, we demonstrate part of the mechanism of action of this novel $\mathrm{Ru}(\mathrm{II})$ PDT agent.

\section{RESULTS AND DISCUSSION}

Synthesis and Spectral Characteristics of Ru(II) Complexes. The ligands and $\mathrm{Ru}$ (II) complexes employed in the present studies are shown in Figure 1a. In the design of 4 and $\mathbf{5}$, we anticipated that further extension of the flat, planar well-known dppz structure ${ }^{31}$ would increase DNA binding ability, which would be concomitantly felt in modulation of their photophysical properties. This was informed from our recent study of the interaction of the quaternarized pdppz ligand with $\mathrm{DNA}^{31}$ In the case of $\mathbf{5}$ it was envisaged that incorporation of a "TAP-like" moiety on the ligand in tandem with variation of the ancillary ligands would confer both increased DNA binding and photocleavage ability with possible formation of DNA-photoadducts, as has been seen previously with $\mathrm{Ru}(\mathrm{II})$ complexes containing TAP ligands. ${ }^{32,33}$ The synthetic pathway of $\mathbf{4}$ and $\mathbf{5}$ is shown in Figure 1a (see Supporting Information for experimental data). In short, the synthesis of 3 was achieved by condensation of 5,6diaminoquinoxaline ${ }^{34} \quad 1$ with 1,10-phenanthroline-5,6dione $\mathrm{e}^{31,35} \mathbf{2}$ by reflux in EtOH, yielding 3 as a gray solid in $95 \%$ yield. The microwave irradiation of 3 in the presence of the appropriate ruthenium bispolypyridyl dichloride ${ }^{36}$ for 15 min followed by precipitation from water using excess ammonium hexafluorophosphate yielded the crude complexes 4 and 5 in $69 \%$ and $52 \%$ yield, respectively, after purification. Synthesized as their chloride salts, all complexes are watersoluble, and their photophysical properties were investigated in $10 \mathrm{mM}$ phosphate buffered aqueous solutions at $\mathrm{pH}$ 7.4.

Red prism shaped crystals were obtained of the hexafluorophosphate complex of $\mathbf{5}$ by slow evaporation from acetonitrile. The X-ray crystal structure of $\mathbf{5}$ is shown in Figure $1 \mathrm{~b}$ and confirms the incorporation of two TAP ligands and the extended planar pdppz ligand around the $\mathrm{Ru}(\mathrm{II})$ center. The complex crystallized in a triclinic system with space group $P \overline{1}$, and the unit cell contains two complexes (the $\delta$ and $\lambda$ enantiomers) and four hexafluorophosphate counteranions. Complex $\mathbf{5}$ exhibits a distorted octahedral geometry, with $\mathrm{Ru}-$ $\mathrm{N}$ bond distances lying in a narrow range between $2.060(3)$ and 2.086(3) Å. $\left[\mathrm{Ru}(\mathrm{TAP})_{2} \mathrm{dppz}\right]^{2+}, 6$, was synthesized according to a modification of the literature procedure reported by Kirsch-De Mesmaeker et al., ${ }^{23}$ and its chemical structure is shown in Figure 1c.

The characteristic UV-vis absorbance spectra together with the excitation and emission spectra of $\mathbf{4}$ and $\mathbf{5}$ are shown in the Supporting Information, showing transitions that are typical of related compounds such as dipyrido[3,2-a:2', $\left.3^{\prime}-c\right]$ phenazine (dppz). 5 possesses a band at $308 \mathrm{~nm}$ due to the pdppz ligand and a broad structured band centered at $415 \mathrm{~nm}$ which is attributed to the MLCT transitions of the $\mathrm{Ru}(\mathrm{II})$ center. Excitation of 5 at $415 \mathrm{~nm}$ in aqueous $\mathrm{pH} 7.4$ buffered solution gave rise to MLCT based emission with $\lambda_{\max }$ at $630 \mathrm{~nm}$. This is similar behavior to that observed for $\mathrm{Ru}(\mathrm{TAP})_{2}(\mathrm{dppz})^{23}$ which can be justified if the lowest excited MLCT state is due to a charge transfer to one of the two TAP ligands. As expected, no MLCT based emission was observed for the control complex 4.

In the first step to profile the biological activity of 5 the DNA binding affinity was investigated. A series of DNA titrations were carried out in $10 \mathrm{mM}$ phosphate buffer at $\mathrm{pH}$ 7.4. The addition of salmon testes (st) DNA to $\mathbf{4}$ and $\mathbf{5}$ resulted in significant changes to their absorption spectra which are summarized in Supporting Information. These showed that in the case of 4 a $53 \%$ hypochromism was observed for the pdppz band (located at $308 \mathrm{~nm}$ ), while the MLCT band experienced a $30 \%$ hypochromism. For structure 5, a hypochromism of $43 \%$ and $30 \%$ was seen for these two transitions, respectively. These defined hypochromicities would indicate intercalation of the pdppz ligand between the stacked bases. The intrinsic binding constant $(K)$ and binding site stoichiometry $(n)$ were determined from these spectroscopic results using the model of Bard et al. ${ }^{37}$ (see Supporting Information), which showed that 4 and 5 had high affinity for DNA, with $K=1.2 \times 10^{7} \mathrm{M}^{-1}$ $( \pm 0.3)$ and $n=1.45( \pm 0.03)$ for 4 , while for $5 \mathrm{~K}=5.4 \times 10^{6}$ $\mathrm{M}^{-1}( \pm 0.5)$ and $n=1.55( \pm 0.02)$. In the presence of $100 \mathrm{mM}$ $\mathrm{NaCl}$, the resulting $K$ values were found to be in the region of $10^{6} \mathrm{M}^{-1}$ (Supporting Information), indicating that binding strength is only moderately sensitive to salt concentration. In agreement with the ground state studies, significant changes were also seen in the emission spectra of $\mathbf{4}$ and $\mathbf{5}$ upon binding to DNA (see Supporting Information). Compound 4 is best described as a "light switch" for DNA, as it showed no significant luminescence in aqueous buffer solution (as has been demonstrated for other phen based polypyridyl Ru complexes containing one or more dppz structures), as upon addition of st-DNA, intense MLCT-based photoluminescence was observed, centered at $620 \mathrm{~nm}$ (Supporting Information). ${ }^{56}$ Complex 5 exhibits opposite behavior upon addition of stDNA, where the intense luminescence of $\mathbf{5}$ in aqueous buffer is effectively quenched upon addition of DNA, behavior which is also characteristic of the excited MLCT Ru-TAP state where the excited state is localized on the TAP ligand. [Ru$\left.(\mathrm{TAP})_{2}(\mathrm{~L})\right]^{2+}$ complexes $(\mathrm{L}=\text { phen or bpy })^{16,38}$ have been shown to photo-oxidize guanine containing nucleotides. Therefore, the emission of $\mathbf{5}$ was next investigated in the presence of $[\operatorname{poly}(\mathrm{dA}-\mathrm{dT})]_{2}$ and $[\operatorname{poly}(\mathrm{dG}-\mathrm{dC})]_{2} .{ }^{57}$ For the former, a marked 57\% increase in the MLCT emission intensity was observed, induced by the protection afforded upon intercalation into the double helix from oxygen based quenching. Conversely, in the case of $[\operatorname{poly}(\mathrm{dG}-\mathrm{dC})]_{2}$, a dramatic $98 \%$ luminescence decrease was observed most likely due to the aforementioned photooxidation process. Analysis of the binding of these complexes by linear dichromism (LD) spectroscopy further supported the intercalative nature of binding of both complexes to DNA (see Supporting Information).

Having demonstrated the high affinity of 5 for DNA, we next considered the DNA photocleavage ability of the complex. In order to evaluate this for $\mathbf{4}$ and $\mathbf{5}$, agarose gel electrophoresis of pBR322 plasmid DNA was undertaken (Figure 2). When incubated in the dark, neither complex showed any DNA cleavage. However, 5 showed extremely efficient photocleavage after $30 \mathrm{~min}$ of irradiation under aerobic conditions at a DNA phosphate to $\mathrm{Ru}(\mathrm{II})$ dye $(P / D)$ ratio of 100 . Furthermore, at $P / D=50$ the complex showed complete conversion of the supercoiled DNA to both nicked and linear forms. As expected, 


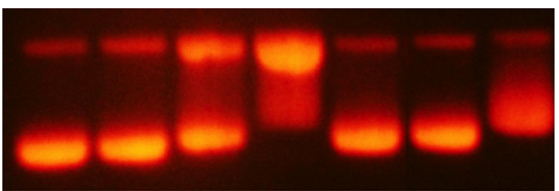

$\begin{array}{lllllll}1 & 2 & 3 & 4 & 5 & 6 & 7\end{array}$

Figure 2. Agarose gel electrophoresis of pBR322 DNA ( $1 \mathrm{mg} / \mathrm{mL})$ after irradiation $\left(2 \mathrm{~J} \mathrm{~cm}^{-2}\right)$ at $\lambda>390 \mathrm{~nm}$ in $10 \mathrm{mM}$ phosphate buffer, $\mathrm{pH}$ 7. 4. Lane 1: plasmid DNA control. Lane 2 : $\left[\mathrm{Ru}(\mathrm{bpy})_{3}\right]^{2+}(P / D$ of 100). Lanes 3-4: $5(P / D$ of 100,50$)$. Lane 5: 5 in the dark $(P / D$ of 100). Lanes 6 and 7: $4(P / D$ of 100,50$)$.

complex 4 did not show a marked increase in the formation of either linear or nicked DNA strands.

Cellular Uptake of Ru(II) Polypyridyl Complexes. The uptake and cellular localization of $\mathbf{4}$ and $\mathbf{5}$ in the dark (no photoactivation) in a cervical cancer cell line (HeLa) were investigated. Confocal fluorescence microscopy was used to track the red emission arising from the complexes ${ }^{18}$ over a period of 4,8 , and $24 \mathrm{~h}$. Complexes appeared to move from the outside of the cell toward the nucleus in a time-dependent manner. Here discrete "packets" of luminescence in the cytoplasm were observed at all time points with complex 4 and at short time points $(4 \mathrm{~h})$ for complex 5 . A large single intense luminescent spot (at the resolution of confocal microscopy) was observed after $8 \mathrm{~h}$ associated near the nucleus for complex $\mathbf{5}$ as demonstrated in Figure 3a. Concomitant with this single location was the observation of a concave or beanshaped nucleus. After $24 \mathrm{~h}$ compound $\mathbf{5}$ appeared to localize around the nucleus. An enlargement of a representative cell treated with $\mathbf{5}$ is shown for illustrative purposes in Figure $3 \mathrm{~b}$. It should be noted that the difference between the emission properties of $\mathbf{4}$ and $\mathbf{5}$ could account for the lower visualization of 4 in the cytoplasm at earlier time points. The fact that cellular uptake was found to be temperature-dependent suggests that these compounds are not membrane-permeable and require active or facilitated uptake (Figure 3c).

The control compound 6 was similarly observed to localize in the cytoplasm of HeLa cells; however, uptake appeared to be slower with the compound only clearly visible within cells after $24 \mathrm{~h}$. Previous studies have shown that extending the size of the polypyridyl ligand confers lipophilic character to the complexes and results in enhanced uptake into cells ${ }^{2,18}$ (Supporting Information).

Uptake of Compounds into Isolated Organelles. As these compounds were shown to bind to st-DNA but did not appear to localize within the nucleus of whole cells, organelles were isolated from rat liver tissue and incubated for $20 \mathrm{~min}$ with complexes $\mathbf{4}$ and $\mathbf{5}$. Both compounds were shown to be taken
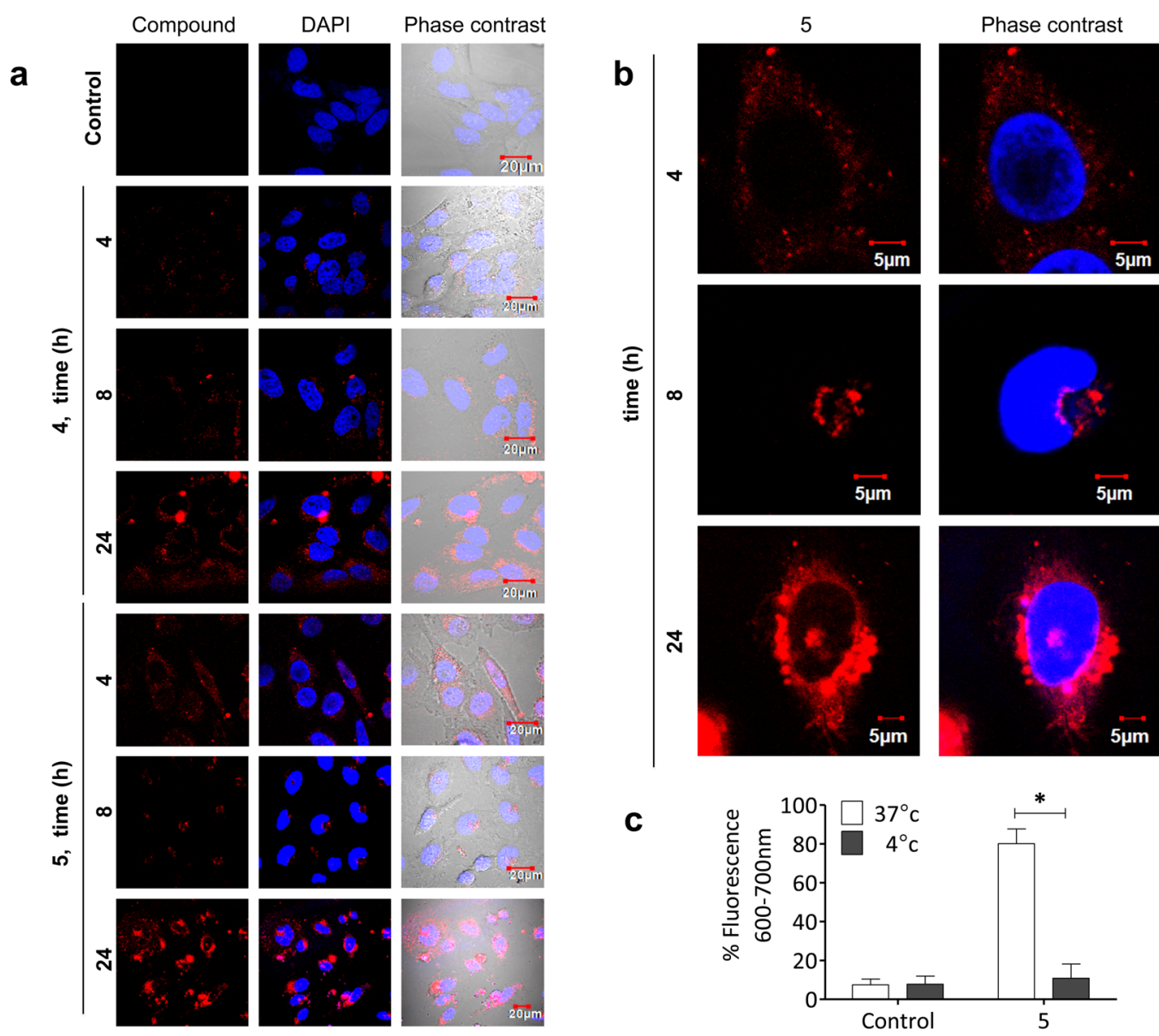

Figure 3. Time dependent localization of $\mathbf{4}$ and $\mathbf{5}$ in HeLa cells. $0.5 \times 10^{5} \mathrm{HeLa}$ cells were treated as required, washed twice, incubated with DAPI (Blue nuclear stain), and viewed using an Olympus FV1000 point scanning microscope with a $60 \times$ oil immersion lens with an NA of 1.42 . (a) Cells were treated with $100 \mu \mathrm{M} 4$ or 5 for 4, 8, or $24 \mathrm{~h}$. (b) Cells were treated with $100 \mu \mathrm{M} 5$ for $24 \mathrm{~h}$; enlargement of representative cells for illustrative purposes. (c) Cells were treated with $100 \mu \mathrm{M} 5$ for $4 \mathrm{~h}$ at 37 or $4{ }^{\circ} \mathrm{C}$, and the percentage of cells with compound fluorescence was expressed over the total amount of cells (approximately 50) per field of view. Data points represent the mean \pm SEM. 


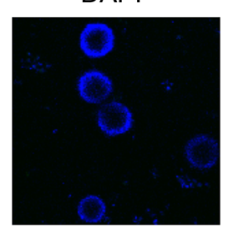

Phase contrast

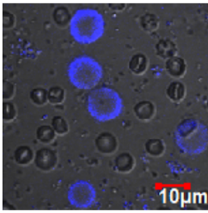

b

4

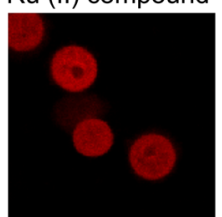

5

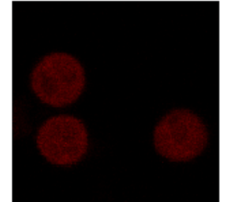

Phase contrast
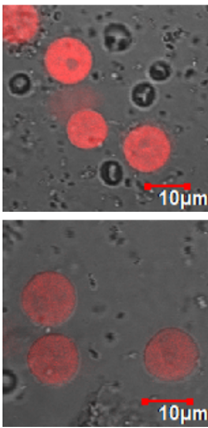

Figure 4. Rat liver nuclei show uptake of compounds 4 and $\mathbf{5}$. Nuclear-rich fractions isolated from rat liver tissue were treated with $100 \mu \mathrm{M} 4$ or 5 for $20 \mathrm{~min}$ before organelles were washed with PBS and viewed by confocal microscopy. Isolated nuclei stained with (a) DAPI and (b) Ru(II) complex 4 or 5 .

up by isolated, intact nuclei (Figure 4a,b). Compound $\mathbf{5}$ was shown to have a decreased luminescence intensity when compared with compound 4, as was predicted based on the observed quenching of $\mathbf{5}$ when bound to DNA, as discussed above. The compounds stained the nucleus in a similar manner to DAPI.

Investigation into the Subcellular Localization and Light Activation of Compounds 4 and 5. The results listed above confirm the ability of the compounds to bind not only to isolated st-DNA but also to DNA in its natural environment within a mammalian nucleus. However, when these complexes are incubated with whole cells, the compounds fail to reach the nucleus. In order to investigate why this occurred, we looked at the subcellular localization of the compounds in whole cells using confocal fluorescence microscopy and examining the colocalization of $\mathbf{5}$ with mitochondria (Figure 5a), lysosomes (Figure 5b), and the endoplasmic reticulum (Figure 5c). The results of these experiments suggest that $\mathbf{5}$ appears to colocalize to mitochondria and/or lysosomes (Figure $5 \mathrm{a}-\mathrm{d}$ ).

Further analysis of $\mathrm{Ru}(\mathrm{II})$ complex localization using transmission electron microscopy (TEM) of HeLa cells revealed that $\mathbf{5}$ accumulates in mitochondria as indicated by the dense staining of HeLa cell mitochondria treated with 5 (Figure 6a). Previously, dinuclear Ru(II) polypyridyl complexes prepared by the Keene group have been observed to also accumulate in the mitochondria. ${ }^{3}$ The TEM imaging experiments also confirm the clustering of loaded mitochondria near the nucleus, also known as perinuclear mitochondrial clustering. Compound $\mathbf{5}$ was also shown to reduce the mitochondrial membrane potential (MMP) of HeLa cells in vitro after $30 \mathrm{~min}$ but with apparent recovery after $4 \mathrm{~h}$, showing the reduction in MMP to be time-dependent and further confirming the accumulation of $\mathbf{5}$ in mitochondria (Figure $6 \mathrm{~b}, \mathrm{c}$ ). Compound 4 also reduced the MMP of HeLa cells (Figure 6d) but, unlike that seen for $\mathbf{5}$ above, without recovery even after $8 \mathrm{~h}$.

In order to evaluate the cytotoxic anticancer potential of 4 and 5, both were tested for cytotoxicity in five cancer cells lines: two mesothelioma cell lines, the cervical cancer cell line, HeLa, and two Burkitt's lymphoma cell lines. As these complexes could potentially exhibit "light-switch" cytotoxicity inside the cells upon light activation, both compounds were "photoactivated" using low intensity light $\left(\lambda \geq 400 \mathrm{~nm}, \sim 18 \mathrm{~J} \mathrm{~cm}^{-2}\right)$ upon incubation in cells and assessed. Of the two complexes, 4 showed no light dependent cytotoxicity at high concentrations in the various cell lines (Table 1). In contrast to these results, compound $\mathbf{5}$ displayed light-dependent cytotoxicity in HeLa and mesothelioma cells (CRL5915) in a concentration dependent manner (Table 1) with minimal dark toxicity which was observed only at higher concentrations. These results demonstrate that the activity of the complex is achieved by simple light activation as is clear from determining the $\mathrm{IC}_{50}$
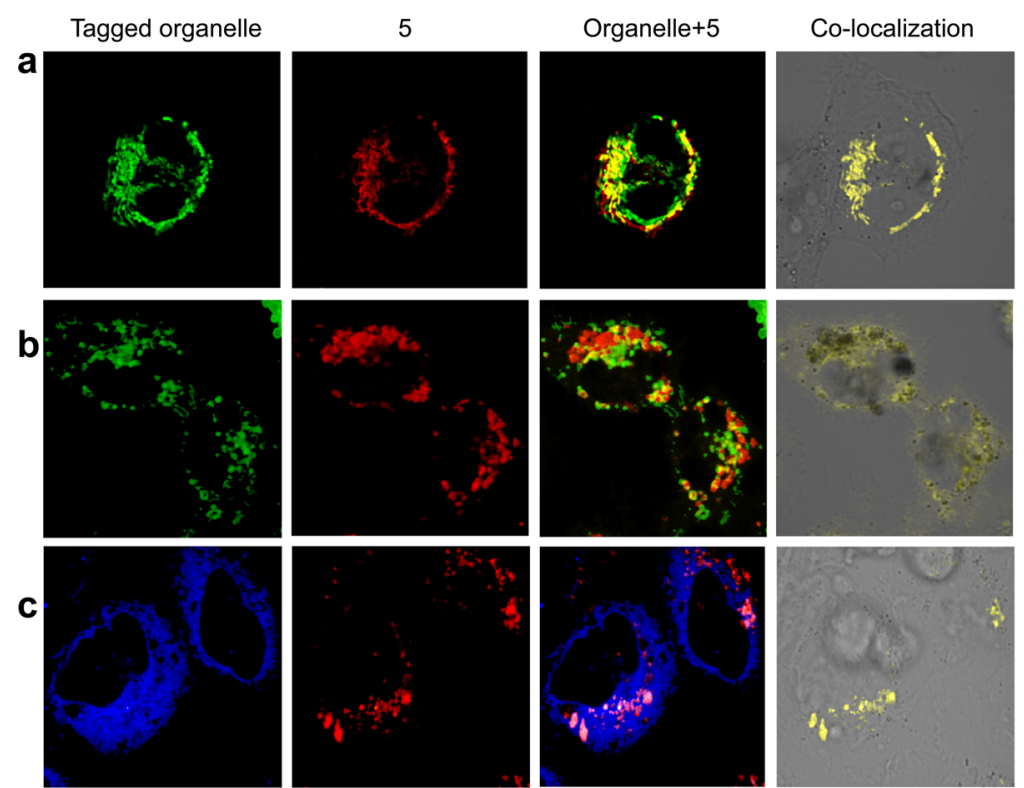

d

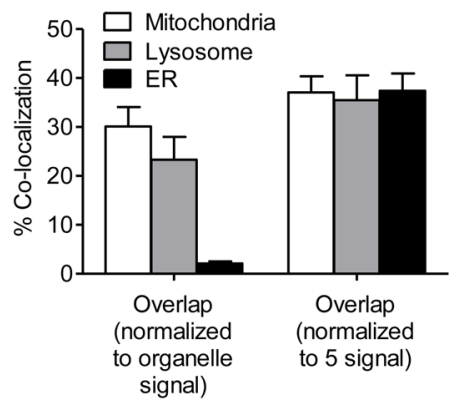

Figure 5. Subcellular location of $\mathbf{5}$. Assessment of colocalization of 5 with mitochondria (a, d), lysosomes (b, d), and endoplasmic reticulum (ER) (c, d). 
a
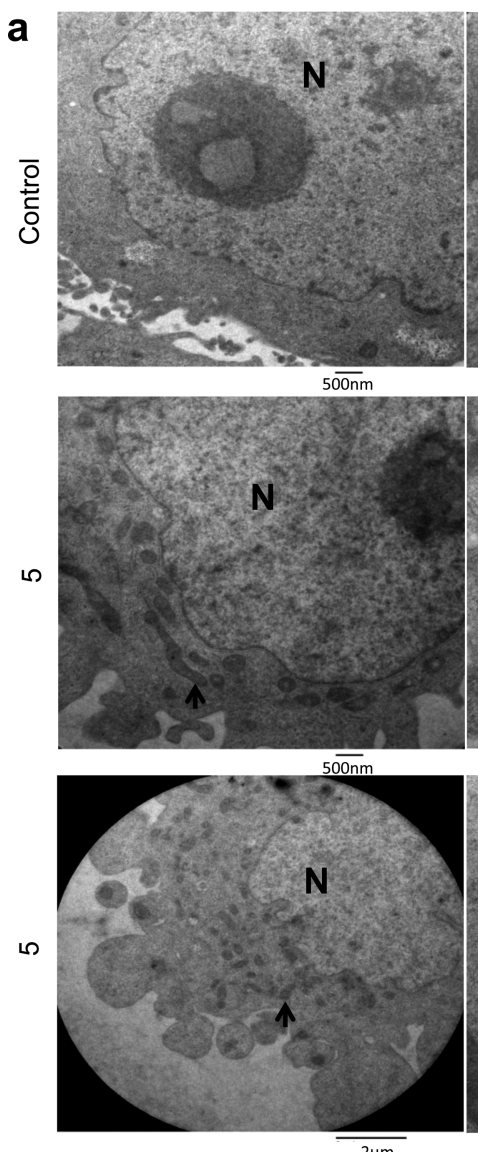

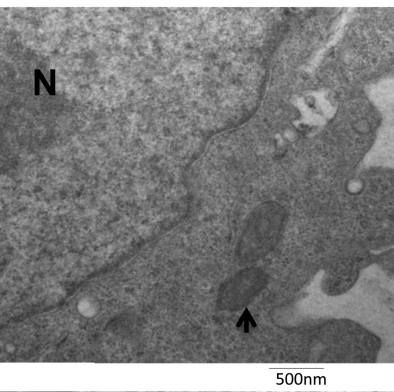

$500 \mathrm{~nm}$
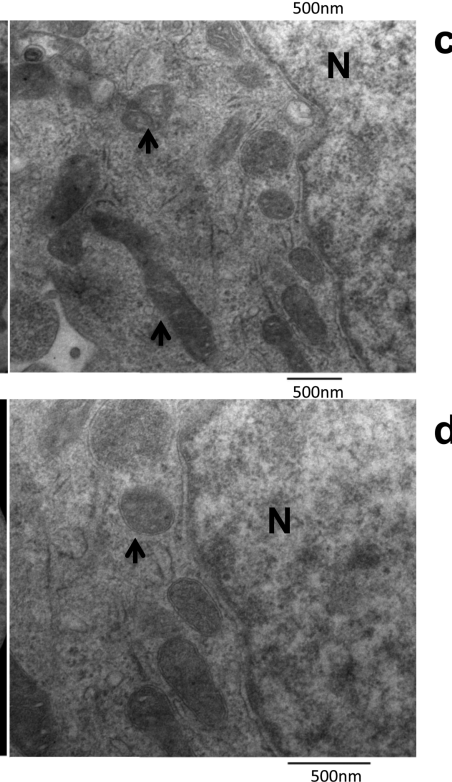

b

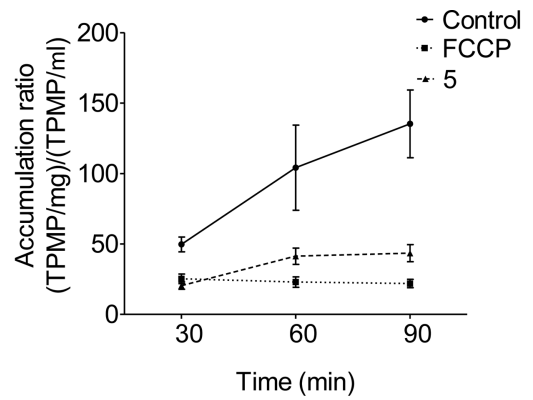

C

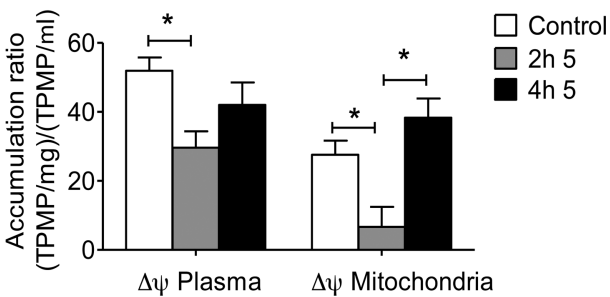

d

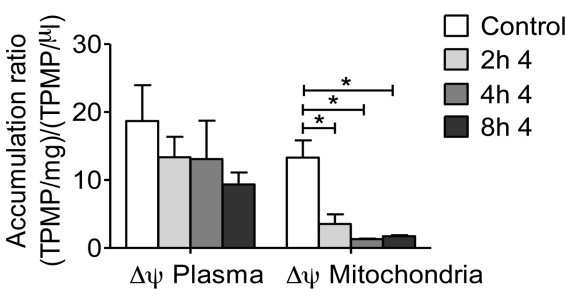

Figure 6. Effect of $\mathrm{Ru}$ (II) complexes on mitochondria. TEM of HeLa cells untreated (control), or treated with $100 \mu \mathrm{M} 5$ at different magnifications. Shown are the effects of $5(\mathrm{~b}, \mathrm{c})$ and $\mathbf{4}(\mathrm{d})$ on TPMP accumulation, a direct measure of MMP: N, nucleus; arrowheads, mitochondria. Statistical analysis was performed using a one-way ANOVA: $*, p<0.05$. Data points represent the mean \pm SEM.

Table 1. Effects of Ru(II) Complexes 4 and 5 on Malignant Cell Lines with or without Light Activation ${ }^{a}$

\begin{tabular}{llllc} 
& \multicolumn{4}{c}{$\mathrm{IC}_{50}(\mu \mathrm{M})$} \\
\cline { 2 - 5 } HeLa & \multicolumn{1}{c}{ 4, dark } & \multicolumn{1}{c}{ 4, light } & \multicolumn{1}{c}{ 5, dark } & \multicolumn{1}{c}{ 5, light } \\
CRL 5915 & $73.3 \pm 17.7$ & $92.3 \pm 190$ & $70 \pm 6.3$ & $8.8 \pm 2.9$ \\
One58 & $53.2 \pm 11.5$ & $62.2 \pm 9.3$ & $>100$ & $42.8 \pm 2.6$ \\
Mutu-I & $>100$ & $>100$ & $40.2 \pm 3.5$ & $17.6 \pm 1.4$ \\
DG-75 & $>100$ & $90 \pm 13.8$ & $>100$ & $42.5 \pm 0.8$
\end{tabular}

$a(1-5) \times 10^{3}$ cells/well were seeded in a 96-well plate and treated with the respective drug for $24 \mathrm{~h} \pm$ irradiation with $18 \mathrm{~J} \mathrm{~cm}^{-2}$ of light. After $24 \mathrm{~h}$, each well was then treated with $20 \mu \mathrm{L}$ of Alamar Blue and left to incubate at $37^{\circ} \mathrm{C}$ in the dark for 4-6 h. Fluorescence was read at $590 \mathrm{~nm}$ (excitation $544 \mathrm{~nm}$ ). The background fluorescence of the media without cells + Alamar Blue was taken away from each group, and the control untreated cells represented $100 \%$ cell viability. Data represent the mean \pm SEM.

values for the cytotoxicity of $\mathbf{5}$ in these cell lines when exposed to light which were found to be between 8.8 and $43 \mu \mathrm{M}$, compared to the $\mathrm{IC}_{50}$ values of between $40.2 \mu \mathrm{M}$ and greater than $100 \mu \mathrm{M}$ for the cell lines tested for the cytotoxicity of $\mathbf{5}$ in the dark. The low cytotoxicity observed for $\mathbf{4}$ suggests that this complex may be used as a luminescent cellular probe within these cell lines, whereas complex $\mathbf{5}$ may have more applications as a novel PDT agent. This clearly demonstrates the enormous scope that such complexes have within biology, where simple structural modifications can dictate the function of the resulting $\mathrm{Ru}(\mathrm{II})$ polypyridyl complex. The control 6 was also assessed for light activation, and these results demonstrated comparable photoinduced toxicity to 5 (Supporting Information).

Photoactivation of $5(100 \mu \mathrm{M})$ in vitro was monitored using real-time confocal microscopy (image taken every $10 \mathrm{~min}$ for $12 \mathrm{~h}$ ) and resulted in cells with an apoptotic phenotype. Using light irradiation alone, in the absence of compound 5, or using compound $\mathbf{5}$ alone in the absence of light irradiation, there was no effect on HeLa cells. Photoactivated cell death was also found to be time-dependent as demonstrated in Figure 7a. Further analysis of the mechanism of cell death elicited by this compound using PI (propidium iodide) FACS (fluorescent activated cell sorter) analysis, which detects the formation of apoptotic bodies, revealed the induction of light-induced apoptosis in a dose- and time-dependent manner, shown in Figure $7 \mathrm{~b}$ and Figure $7 \mathrm{c}$, respectively. Light-induced cell death was rapid and potent $(70-80 \%$ cell death at $100 \mu \mathrm{M})$ with the dark death effect being minimal (6-8\% cell death at 10 and 100 $\mu \mathrm{M})$. Recent investigations into the anticancer effects of $\mathrm{Ru}(\mathrm{II})$ polypyridyl complexes document $\mathrm{IC}_{50}$ values of between 5 and $500 \mu \mathrm{M}$ in the absence of light, implying a weak "dark" toxic effect. $^{39}$ Other $\mathrm{Ru}(\mathrm{II})$ complexes have been previously examined as PDT agents, with $\mathrm{Ru}(\mathrm{II})$ phthalocyanine, $\mathrm{Ru}(\mathrm{II})$ 2,3-naphthalocyanines having been shown to display phototoxicity in the low micromolar range $\mathrm{e}^{30,40}$ which is comparable to that found in the present study. Previous literature on the efficacy of nonporphyrin PDT agents report $\mathrm{IC}_{50}$ values of 
a

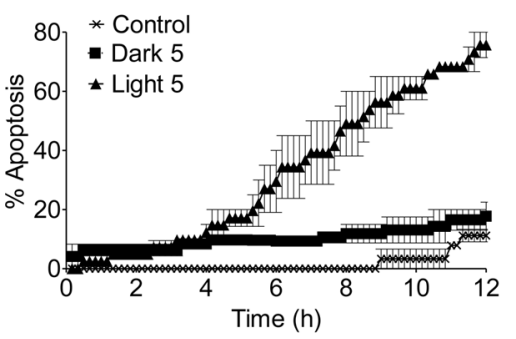

d
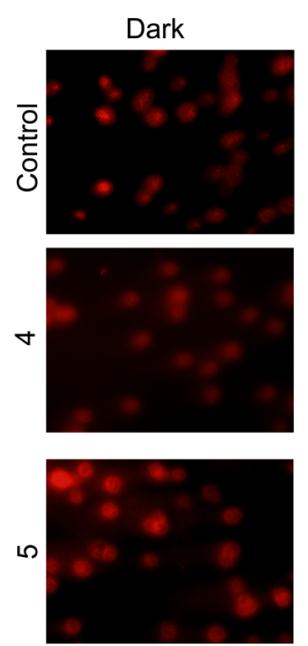

b

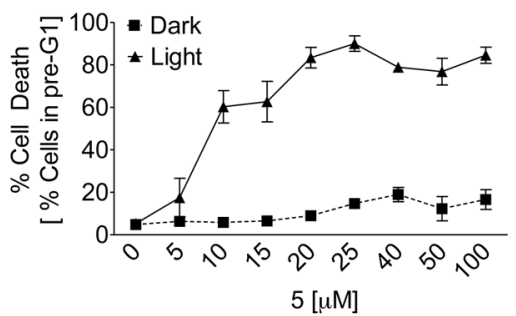

e
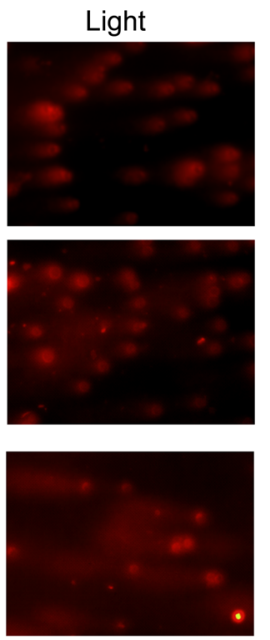

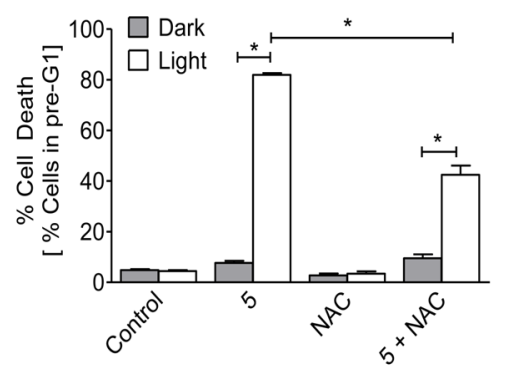

g
C

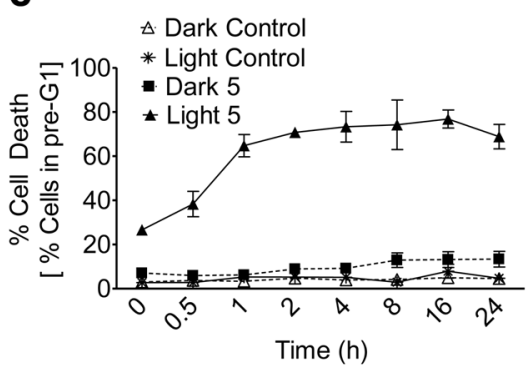

f

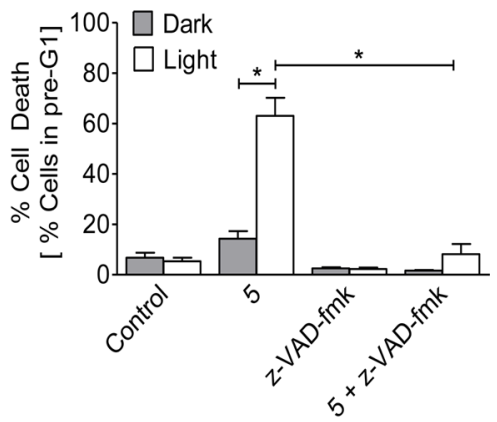

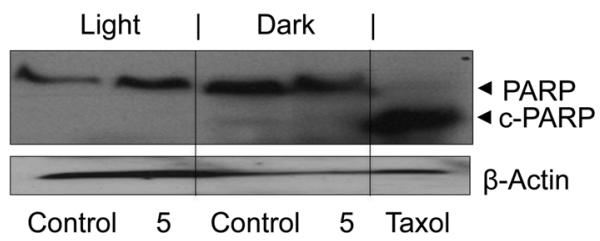

Figure 7. $\mathrm{Ru}(\mathrm{II})$ complex 5 induces programmed cell death of HeLa cells. $(1-5) \times 10^{3}$ cells/well were seeded and treated with the respective drug for $24 \mathrm{~h} \pm$ irradiation with $\sim 18 \mathrm{~J} \mathrm{~cm}^{-2}$ of light followed by incubation for the indicated time-points or a further $24 \mathrm{~h}$. Confocal microscopy was used to assess cells for the appearance of apoptotic cells (a). PI staining was used to assess the effect of concentration (b), time (c), ROS inhibition (e), and caspase inhibition (f) on $\mathrm{Ru}(\mathrm{II})$ complex 5 light-induced toxicity. Intracellular DNA strand breakage was identified via the comet assay (d), and cleavage of the enzyme PARP was identified through Western blotting $(\mathrm{g})$ following treatment with 5. Statistical analysis was performed using a oneway ANOVA: $*, p<0.05$. Data points represent the mean \pm SEM.

between $63 \mathrm{nM}$ and $8 \mu \mathrm{M}$ in the light compared to between 27 $\mu \mathrm{M}$ and $>100 \mu \mathrm{M}$ in the dark. ${ }^{41,42}$

In our study, cells treated with $\mathbf{5}$ and light irradiation showed a significant degree of single stranded DNA migration and damage compared to dark controls as demonstrated by the single cell gel electrophoresis comet assay (Figure 7d). Cells treated with $\mathbf{4}$ and irradiation also underwent a small amount of DNA damage; however, this was in no way to the same extent as was observed for 5-treated cells, as illustrated by shorter comet tails.

As some other PDT agents elicit their cell death effects through the activation of reactive oxygen species (ROS), we utilized the antioxidant $\mathrm{N}$-acetylcysteine (NAC) to investigate the involvement of ROS in photoinduced programmed cell death mediated by $\mathbf{5}$. HeLa cells preincubated with NAC (5 $\mathrm{mM}$ ) for $1 \mathrm{~h}$, treated with $\mathbf{5}$, and activated with light were not found to undergo the same amount of cell death as those cells without NAC as illustrated in Figure 7e. These results suggest that ROS are involved in the photoinduced cell death and that complex $\mathbf{5}$ may induce a "classical" PDT response in cells as observed with other PDT agents. The involvement of ROS, which are formed in mitochondria, again supports the involvement of $\mathbf{5}$ with mitochondria. However, it is important to point out that non-oxygen dependent photoreaction pathways of $\mathrm{Ru}(\mathrm{II})$ (TAP) complexes with biomolecules have also been reported. ${ }^{43,44}$

The cell death induced by 5 was inhibited by pretreating the cells for $4 \mathrm{~h}$ with $40 \mu \mathrm{M}$ general caspase inhibitor z-VAD-fmk (Figure 7f). Caspases are intracellular cysteine proteases involved in forms of programmed cell death, and these results further confirmed the cells were undergoing apoptosis that was light induced. Caspases are sometimes known to cleave the DNA repair enzyme PARP (poly(ADP-ribose) polymerase) from a $113 \mathrm{kDa}$ molecule into 89 and $24 \mathrm{kDa}$ fragments during apoptosis. However, this was not found to be the case with $\mathbf{5}$, as no induced PARP cleavage was observed (Figure $7 \mathrm{~g}$ ). Treatment with paclitaxel was used as a positive control for PARP cleavage. These overall results clearly demonstrate the importance of the presence of the TAP ligand in 5, which is absent in $\mathbf{4}$, and the direct mechanistic effect 5 has on cellular viability. Finally, the ability of a photosensitizer to enter a cell and be eliminated without harming the cell is essential for any effective PDT agent. In this study we examined the effects of 5 on HeLa cells over a 48-96 h time frame using PI FACS analysis and confocal microscopy. Confocal microscopy demonstrated that after 48 and $96 \mathrm{~h}, 5$ is no longer visible in the cell. PI FACS analysis also showed that 5 had no obvious apoptotic effect after $48 \mathrm{~h}$, theoretically reducing any potential 
side effects in vivo (Supporting Information). Collectively, these results support the clinical advancement of complex $\mathbf{5}$ as a potential PDT agent. This complex will be used as a platform for the development of improved structures with higher wavelength absorptions and improved efficacy. A higher absorption wavelength would eliminate any absorption by hemoglobin or other blood proteins in vivo and could also be achieved by using two-photon microscopy instead of conventional confocal (or one-photon) microscopy while still maintaining the same emission spectrum as recently demonstrated with similar Ru polypyridyl compounds. ${ }^{45-47}$ Also of clinical importance, ruthenium compounds are known to bind to high and low density lipoproteins, serum proteins, and albumin in vivo, which have been shown to enhance drug accumulation into the tumor tissue; ${ }^{48,49}$ interestingly, however, a recent study by Pernot et al. on arene ruthenium porphyrin PDT compounds demonstrated that fluence rate in PDT was more important than the photosensitizer concentration. ${ }^{50}$ Conventional chemotherapy targets rapidly dividing cells as opposed to tumor cells, resulting in serious side effects, and while targeted therapies overcome this limitation, they are expensive and only available for a limited number of cancers with specific, well-defined mutations. In contrast, the potential use of complex 5 as a PDT agent would overcome these obstacles, as the very nature of PDT agents ensures that only complexes at the site of interest, a tumor, would be photoactivated to induce cell death in vivo. While nontumor cells found in the tumor region would also likely experience PDT-induced toxicity, the lack of toxicity with nonphotoactivated complexes found in the rest of the body together with the observed clearance of nonphotoactivated complexes from healthy HeLa cells also highlights the development potential of complex 5 .

\section{CONCLUSION}

In this study, we report the synthesis of a new photodynamic therapeutic agent $\mathbf{5}$ and the related control pdppz light-switch complex 4 . The luminescence of 4 significantly increases when bound to DNA, while the luminescence of $\mathbf{5}$ decreases when bound to DNA. While the structures of $\mathbf{4}$ and $\mathbf{5}$ are similar, they have very different mechanisms of action on st-DNA in aqueous solution. While both compounds have been shown to bind DNA with high affinity, gel electrophoresis measurements reveal that only complex 5 cleaves DNA. We further demonstrate that the presence of the TAP ligand in $\mathbf{5}$ is instrumental to the photoactivity of the complex within cells (this we also show to be the case for 6). From our thorough investigation of the biological properties of these complexes, a number of important observations have been made, including that the complexes are found to be actively transported to the interior of the cells and accumulate with clear visualization (600-700 nm range) within the cells after 8 h. Furthermore, the increased lipophilicity of the extended pdppz ligand employed in $\mathbf{4}$ and $\mathbf{5}^{51}$ is found to increase the rate of uptake of the complexes compared to the corresponding dppz containing complex 6. Moreover, the uptake of the complexes 4 and 5 into isolated nuclei indicates that the complexes are capable of displaying MLCT luminescence when bound to DNA within the nuclei, our results confirming that 4 is more emissive compared to $\mathbf{5}$, as seen for the binding of these complexes to isolated st-DNA. However, in live cell imaging, the compounds are found to mostly localize within mitochondria and lysosomes, with lesser amounts found in other organelles such as the endoplasmic reticulum. These results clearly highlight the influence the microenvironment of the cell has on the complexes and the importance of performing such experiments in live cells. Further evidence for the mitochondrial localization of $\mathbf{5}$ was obtained by TEM studies of HeLa cells, which show densely stained mitochondria appearing to localize around the nucleus. Being lipophilic and cationic in nature, we demonstrate that the complexes enter mitochondria, most likely driven by the MMP, with 5 being shown to reduce the MMP within $30 \mathrm{~min}$ of treatment with recovery of the MMP after $4 \mathrm{~h}$. The subsequent perinuclear clustering of compound laden mitochondria may be suggestive of a large degree of depolarization induced mitophagy as described by Youle et al. ${ }^{52}$

The cellular photoreactivity of $\mathbf{5}$ was investigated by assessing the antiproliferative/cytotoxicity in the presence and absence of light irradiation of low intensity $\left(18 \mathrm{~J} \mathrm{~cm}^{-2}\right)$ in a number of malignant cell lines. The complex showed potent light-dependent toxicity in a range of cell lines $\left(\mathrm{IC}_{50}\right.$ values of between 8.8 and $43 \mu \mathrm{M}$ ) and was shown to induce dose and time dependent programmed cell death in HeLa cells; the critical involvement of caspases confirmed this form of programmed cell death to be apoptosis. This could be occurring via an electron transfer mechanism (which is photoinduced driven), which could potentially involve binding of 5 to DNA within the mitochondrion itself, though further investigations would be required to confirm this. Moreover, the light-dependent cytotoxicity of $\mathbf{5}$, which is consistent with ROSmediated apoptosis, was not observed for $\mathbf{4}$, and importantly, in the absence of light activation, complex 5 was found to be cleared from the cells without causing any damage. In addition, compared to commercially available porphyrins, which often consist of a mixture of products, complex $\mathbf{5}$ is pure. $\mathbf{5}$ can also can be easily modified and will be used to further refine the structure-activity relationship required for even more potent PDT agents. Studies are also currently underway to develop analogues of $\mathbf{5}$ that can be photoactivated by longer wavelengths of light to allow for even better tissue penetration. It should be noted that while other investigators have described mitochondrial uptake of $\mathrm{Ru}(\mathrm{II})$ based polypyridyl compounds, ${ }^{18,25,39}$ a vast majority of these complexes are not photoactive, highlighting the novel importance of the current study.

In summary, complex $\mathbf{5}$ reveals it has promise for development as a new photodynamic therapeutic. It is pure, hydrophilic, easily accumulates in cancer cells, has little dark toxicity, clears the cells within $96 \mathrm{~h}$, can be easily photoactivated, appears to have high singlet oxygen production, and can induce programmed cell death. The increased understanding gained by a comprehensive biological profiling of the activity of this complex brings us one step closer to the use of $\mathrm{Ru}(\mathrm{II})$ polypyridyl complexes to turn on cytotoxicity in cancerous cells, and this has not been demonstrated in such a detailed manner before.

\section{MATERIALS AND METHODS}

Compounds. Synthesis of $\mathrm{Ru}(\mathrm{II})$ polypyridyl complexes and ICPMS sample preparation are described in the Supporting Information. All new compounds were characterized using conventional methods (see full characterization in Supporting Information), which included the use of $600 \mathrm{MHz}$ NMR and elemental analysis (CHN), both of which confirmed that the purity of all compounds made was over $95 \%$ (all ${ }^{1} \mathrm{H}$ and ${ }^{13} \mathrm{C}$ NMR spectra are shown in the Supporting 
Information). Cell culture reagents were obtained from Greiner Bioone, and all other chemicals were obtained from Sigma unless otherwise stated.

Crystallographic Experimental Section. Diffraction data for all compounds were collected on a Bruker APEX 2 DUO CCD diffractometer using graphite-monochromatized Incoatec $\mathrm{I} \mu \mathrm{S} \mathrm{Cu} \mathrm{K} \alpha$ $(\lambda=1.54178 \AA)$ radiation. Crystals were mounted in a cryoloop/ MiTeGen micromount and collected at 100(2) K using an Oxford Cryosystems Cobra low temperature device. Data were collected using $\omega$ and $\varphi$ scans and were corrected for Lorentz and polarization effects. ${ }^{22}$ The structures were solved by direct methods with SHELXS 2013 and refined by full-matrix least-squares procedures on $F^{2}$ using SHELXL-2013 software. ${ }^{24}$ All non-hydrogen atoms were refined anisotropically. Hydrogen atoms, with the exception of those of the water molecule, were added geometrically in calculated positions and refined using a riding model. Hydrogen bond analysis was used to place the hydrogens of the water molecule, and their positions were kept fixed. Details of the data collection and refinement are given in the Supporting Information. CCDC 1012983 contains the supplementary crystallographic data for this paper. These data can be obtained free of charge from The Cambridge Crystallographic Data Centre via www.ccdc.cam.ac.uk/data_request/cif.

Agarose Gel Electrophoresis. The DNA photocleavage studies were carried out by treating pBR322 plasmid DNA $(1 \mathrm{mg} / \mathrm{mL})$ with each of the complexes at varying ratios $(P / D$ of 100,50$)$. The samples were then subjected to $2 \mathrm{~J} \mathrm{~cm}^{-2}$ using a Hamamatsu L2570 $200 \mathrm{~W}$ $\mathrm{HgXe}$ arc lamp equipped with a $\mathrm{NaNO}_{2}$ filter before being separated using $0.8 \%$ agarose gel electrophoresis in a TBE ( $90 \mathrm{mM}$ Tris-borate, 2 $\mathrm{mM}$ EDTA, $\mathrm{pH}$ 8.0) buffer. Electrophoresis was carried out at $5 \mathrm{~V} / \mathrm{cm}$ $(40 \mathrm{~mA}, 90 \mathrm{~V})$. Visualization of the DNA was achieved by staining the gel for 90 min with an aqueous solution of ethidium bromide, which was then illuminated with a transilluminator (Bioblock $254 \mathrm{UV}$ illuminator).

Cell Culture. HeLa, ONE-58, and CRL5915 cells were grown in a cell culture flask using low-glucose Dulbecco's modified Eagle medium supplemented with $10 \%$ fetal bovine serum and $50 \mu \mathrm{g} / \mathrm{mL}$ penicillin/ streptomycin at $37{ }^{\circ} \mathrm{C}$ in a humidified atmosphere of $5 \% \mathrm{CO}_{2}$. MUTU-I and DG-75 cells were cultured in RPMI medium with supplements as listed above; however, MUTU-I cells also required the addition of $1 \mathrm{mM}$ HEPES, $100 \mathrm{mM}$ sodium pyruvate, and $50 \mathrm{mM} \alpha$ thioglycerol in PBS with $20 \mu \mathrm{M}$ bathocuprione disulfonic acid. For photoactivation studies, cells were subjected to $18 \mathrm{~J} \mathrm{~cm}^{-2}$ using a Hamamatsu L2570 $200 \mathrm{~W}$ HgXe arc lamp equipped with a $\mathrm{NaNO}_{2}$ filter.

Viability Assay. For the Alamar blue cytotoxicity test involving $\mathrm{Ru}$ (II) polypyridyl complexes, $(1-5) \times 10^{3}$ cells/well were seeded in a 96-well plate and treated with the respective drug for $24 \mathrm{~h} \pm$ irradiation. After $24 \mathrm{~h}$, each well was then treated with $20 \mu \mathrm{L}$ of Alamar blue (BioSource) (prewarmed to $37^{\circ} \mathrm{C}$ ) and left to incubate at $37^{\circ} \mathrm{C}$ in the dark for 4-6 h. Fluorescence was read using at $590 \mathrm{~nm}$ (excitation $544 \mathrm{~nm}$ ). The background fluorescence of the media without cells + Alamar blue was taken away from each group, and the control untreated cells represented $100 \%$ cell viability. Each compound was screened over a $1 \mu \mathrm{M}$ to $1 \mathrm{mM}$ concentration range in triplicate on two independent days with activity expressed as percentage cell viability compared to vehicle treated controls. All data points (expressed as the mean \pm SEM) were analyzed using GraphPad Prism (version 4) software (GraphPad software Inc., San Diego, CA).

Confocal Microscopy. HeLa cells were seeded at a density of 0.75 $\times 10^{5}$ cells $/ 2 \mathrm{~mL}$, left for $24 \mathrm{~h}$ before treating with 4 or 5 for the indicated length of time. Cells were washed $\times 2$ with new media to remove excess drug and analyzed by live confocal microscopy using an Olympus FV1000 point scanning microscope with a $60 \times$ oil immersion lens with an NA (numerical aperture) of 1.42. The software used to collect images was FluoView, version 7.1 software. For temperature dependent uptake studies, cells were placed at $4{ }^{\circ} \mathrm{C}$ for $30 \mathrm{~min}$ before treatment with 5 for $4 \mathrm{~h}$ at $4{ }^{\circ} \mathrm{C}$. Uptake was assessed at the fluorescence per cell at $600-700 \mathrm{~nm}$, carried out on 300 cells on 3 independent days. For the real-time confocal microscopy experiments with photoirradiation, treated cells were irradiated for $30 \mathrm{~min}$ and phase-contrast images were taken every 10 $\min$ for $12 \mathrm{~h}$

Propidium lodide Staining. For the detection of apoptotic bodies by PI FACS analysis, 250000 cells were treated with the appropriate amount of compound and incubated for a specified time. Cells were harvested by centrifugation at $300 \mathrm{~g}$ for $5 \mathrm{~min}$ and washed with $5 \mathrm{~mL}$ of ice-cold PBS. The pellet was resuspended in $200 \mu \mathrm{L}$ of PBS and $2 \mathrm{~mL}$ of ice-cold $70 \%$ ethanol, and cells were fixed overnight at $4{ }^{\circ} \mathrm{C}$. After fixation, the cells were pelleted by centrifugation at $300 \mathrm{~g}$ for $5 \mathrm{~min}$ and the ethanol was carefully removed. The pellet was resuspended in $400 \mu \mathrm{L}$ of PBS with $25 \mu \mathrm{L}$ of RNase A $(10 \mathrm{mg} / \mathrm{mL}$ stock) and $75 \mu \mathrm{L}$ of propidium iodide $(1 \mathrm{mg} / \mathrm{mL})$. The tubes were incubated in the dark at $37^{\circ} \mathrm{C}$ for $30 \mathrm{~min}$. Cell cycle analysis was performed using appropriate gates counting 10000 cells and analyzed using CELLQUEST software package. For mechanistic studies, cells were preincubated with $40 \mu \mathrm{M}$ z-VAD-fmk or $5 \mathrm{mM} \mathrm{N}$-acetylcysteine before treatment with $\mathbf{5}$ and irradiation, and PI FACS analysis was then performed.

Western Blotting. For the detection of PARP cleavage by Western blot analysis $5 \times 10^{6}$ cells were harvested by centrifugation at $500 \mathrm{~g}$ for $5 \mathrm{~min}$ and the pellet was washed with ice-cold PBS. Cells were resuspended in $60 \mu \mathrm{L}$ of PBS and $60 \mu \mathrm{L}$ of lysis buffer (Laemmli buffer; $62.5 \mathrm{mM}$ Tris- $\mathrm{HCl}, 2 \% \mathrm{w} / \mathrm{v}$ SDS, $10 \%$ glycerol, $0.1 \% \mathrm{w} / \mathrm{v}$ bromophenol blue supplemented with protease inhibitors). Samples were prepared for SDS-PAGE resolved on an $8 \%$ loading gel and transferred onto PVDF membranes. Membranes were probed with anti-PARP (Calbiochem) (recognizes full length $113 \mathrm{kDa}$ PARP as well as the $85 \mathrm{kDa}$ cleaved form) primary antibody followed by incubation with the corresponding IgG HRP conjugated secondary antibody. Membranes were developed using electrochemiluminescence detection.

Colocalization Studies. $0.3 \times 10^{5} \mathrm{HeLa}$ cells were seeded, left for $24 \mathrm{~h}$, and transfected with an excitable (405 nm) GFP mitochondrial/ lysosomal or CFP-tagged ER marker. After $24 \mathrm{~h}$, cells were treated with $5(100 \mu \mathrm{M})$ for $16 \mathrm{~h}$, washed twice with fresh media, and analyzed by live confocal microscopy. The sample was first excited with a $488 \mathrm{~nm}$ laser diode, and the emission of drug was monitored and captured at $600-700 \mathrm{~nm}$. The sample was then excited with a 405 $\mathrm{nm}$ laser diode (GFP) or a green helium-neon laser (CFP), and the emission of the excitable marker was monitored and captured at 495$550 \mathrm{~nm}$ (GFP) or $470-500 \mathrm{~nm}$ (CFP). Both images were then overlaid and analyzed using the Imaris $3 \mathrm{D}$ software analyzer (Bitplane).

Membrane Potential. HeLa cells were incubated for the required times with $\mathrm{Ru}(\mathrm{II})$ complexes followed by the addition of a final concentration of $5 \mathrm{nM}$ TPMP, $100 \mathrm{nCi} / \mathrm{mL}\left[{ }^{3} \mathrm{H}\right] \mathrm{TPMP}$, and $5 \mathrm{nM}$ sodium tetraphenylboron (TPB) for $90 \mathrm{~min}$ with or without $1 \mu \mathrm{M}$ FCCP. After incubation, the cells were pelleted by centrifugation, 100 $\mu \mathrm{L}$ of the supernatant was removed and the cell pellet resuspended in $100 \mu \mathrm{L}$ of $20 \%$ Triton $\mathrm{X}-100$. The radioactivity in the pellet and supernatant was quantitated using a liquid scintillation counter with appropriate quench corrections. Accumulation ratio $=[\mathrm{cpm} / \mathrm{mg}$ (pellet) $] /[\mathrm{cpm} / \mu \mathrm{L}$ (supernatant) $] . \mathrm{MMP}=$ accumulation ratio without FCCP - accumulation ratio with FCCP.

Transmission Electron Microscopy. TEM was carried out as previously described. ${ }^{53}$ In brief, $1 \times 10^{6}$ cells were treated with $100 \mu \mathrm{M}$ 5 for $24 \mathrm{~h}$, fixed with $4 \%$ glutaraldehyde for $1 \mathrm{~h}$, washed in $0.5 \mathrm{M}$ phosphate, solidified in $2 \%$ warm agarose solution at $4{ }^{\circ} \mathrm{C}$ for $30 \mathrm{~min}$, and cut into small slices. Slices were further fixed in $2 \%$ osmium tetroxide $\left(\mathrm{O}_{2} \mathrm{O}_{4}\right)$ solution in $0.05 \mathrm{M}$ potassium phosphate buffer and dehydrated using an increasing alcohol series. Pellets were embedded in a $50 \%$ resin solution for $2-3 \mathrm{~h}$ and a $100 \%$ epoxy. Ultrathin sections were cut on an ultramicrotome and collected on copper grids and counterstained with uranyl acetate and lead citrate. Ultrastructural examination was carried out in a JEOL 1210 electron microscope. Images were taken with a $1500-3000 \times$ objective $(2 \mu \mathrm{M}$ scale bars $)$. A number of images were obtained as a representative of each sample.

Comet Assay. HeLa cells were treated with $10 \mu \mathrm{M} 4$ or $20 \mu \mathrm{M} 5$ for $24 \mathrm{~h} \pm$ irradiation and incubated for a further $6 \mathrm{~h}$. Following that, cells were trypinized and resuspended in low melting point agarose 
(LMPA) and added to slides precoated with normal melting point agarose (NPA). Slides were then lysed (2.5 M NaCl, $100 \mathrm{mM}$ EDTA, $10 \mathrm{mM}$ Tris, $1 \%(\mathrm{v} / \mathrm{v})$ Triton $\mathrm{X}-100, \mathrm{pH} 10)$ for $2 \mathrm{~h}$ at $-20^{\circ} \mathrm{C}$ and transferred to an alkaline buffer $(300 \mathrm{mM} \mathrm{NaOH}, 1 \mathrm{mM}$ EDTA, pH $>13$ ) for $20 \mathrm{~min}$ to allow for unwinding of DNA and expression of alkali-labile damage. Slides were then subjected to electrophoresis at $24 \mathrm{~V}, 300 \mathrm{~mA}$ for $30 \mathrm{~min}$. Samples were then neutralized in $0.4 \mathrm{M}$ Tris, $\mathrm{pH}$ 7.5, for $20 \mathrm{~min}$ and stained with PI. Slides were viewed using an Olympus IX81 microscope with a $20 \times$ lens. The software Cell ${ }^{\wedge} \mathrm{P}$ was used to collect images.

Statistical Analysis. Data were analyzed with the software Prism GraphPad using a one-way ANOVA. For illustrative purposes the $p$ values are presented as $*, p<0.05$.

\section{ASSOCIATED CONTENT}

\section{S Supporting Information}

Additional experimental procedures, synthesis and characterization, NMR spectra, mass spectra, crystal data and structure refinement results, UV-vis and fluorescence emission spectra, calculation of binding constants, agarose gel electrophoresis results, and a cif file of crystallographic information. The Supporting Information is available free of charge on the ACS Publications website at DOI: 10.1021/acs.jmedchem.5b00451.

\section{AUTHOR INFORMATION}

\section{Corresponding Authors}

*T.G.: e-mail, gunnlaut@tcd.ie; fax, +353 1 6712826, phone, +35318963459.

*D.C.W.: e-mail, clive.williams@tcd.ie; fax, +353 1 8963130; phone, +35318963964.

\section{Present Addresses}

${ }^{\Delta}$ S.M.C.: Division of Pulmonary and Critical Care Medicine, Department of Medicine, Weill Cornell Medical College, A-337 Laboratory, 1300 York Avenue, New York, NY 10065.

${ }^{\Psi}$ R.B.P.E.: Department of Chemistry, Maynooth University, National University of Ireland, Maynooth, Ireland.

\section{Author Contributions}

"S.M.C. and R.B.P.E. contributed equally.

The manuscript was written through contributions of all authors. All authors have given approval to the final version of the manuscript.

\section{Notes}

The authors declare no competing financial interest.

\section{ACKNOWLEDGMENTS}

We thank Science Foundation Ireland (Grants SFI RFP 2009, SFI 2010 PI, and 2013 PI), HEA PRTLI Cycle 4, The Irish Research Council for Science, Engineering and Technology (IRCSET Postgraduate Studentship to R.B.P.E.), Master and Back Altaformazione Programma, 2009, Autonomous Region of Sardinia, and TCD for financial support.

\section{ABBREVIATIONS USED}

dppz, dipyrido[3,2-a:2', $\left.3^{\prime}-c\right]$ phenazine; FACS, fluorescent activated cell sorter; LD, linear dichroism; MCLT, metal charge to ligand transfer; MMP, mitochondrial membrane potential; NAC, $\mathrm{N}$-acetylcysteine; TAP, tetraazaphenanthrene; TEM, transmission electron microscopy; pdppz, [2,3-h]dipyrido $\left[3,2-a: 2^{\prime}, 3^{\prime}-c\right]$ phenazine; PDT, photodynamic therapy; phen, 1,10-phenanthroline; PI, propidium iodide; ROS, reactive oxygen species; st-DNA, salmon testes DNA

\section{REFERENCES}

(1) (a) Mari, C.; Pierroz, V.; Ferrari, S.; Gasser, G. Combination of $\mathrm{Ru}$ (II) complexes and light: new frontiers in cancer therapy. Chem. Sci. 2015, 6, 2660-2686. (b) Vos, J. G.; Kelly, J. M. Ruthenium polypyridyl chemistry; from basic research to applications and back again. Dalton Trans. 2006, 4869-4883.

(2) Schäfer, S.; Ott, I.; Gust, R.; Sheldrick, W. S. Influence of the polypyridyl (pp) ligand size on the DNA binding properties, cytotoxicity and cellular uptake of organoruthenium(II) complexes of the type $\left[\left(\eta^{6}-\mathrm{C}^{6} \mathrm{Me}^{6}\right) \mathrm{Ru}(\mathrm{L})(\mathrm{pp})\right]^{n+}\left[\mathrm{L}=\mathrm{Cl}, n=1 ; \mathrm{L}=\left(\mathrm{NH}_{2}\right)_{2} \mathrm{CS}\right.$, $n=2]$. Eur. J. Inorg. Chem. 2007, 3034-3046.

(3) Pisani, M. J.; Weber, D. K.; Heimann, K.; Collins, J. G.; Keene, F. $\mathrm{R}$. Selective mitochondrial accumulation of cytotoxic dinuclear polypyridyl ruthenium(II) complexes. Metallomics 2010, 2, 393-396.

(4) Huang, H.; Zhang, P.; Yu, B.; Chen, Y.; Wang, J.; Ji, L.; Chao, H. Targeting nucleus DNA with a cyclometalated dipyridophenazineruthenium(II) complex. J. Med. Chem. 2014, 57, 8971-8983.

(5) Niyazi, H.; Hall, J. P.; O'Sullivan, K.; Winter, G.; Sorensen, T.; Kelly, J. M.; Cardin, C. J. Crystal structures of lambda- $[\mathrm{Ru}(\mathrm{phen})$ (2) dppz $](2+)$ with oligonucleotides containing TA/TA and AT/AT steps show two intercalation modes. Nat. Chem. 2012, 4, 621-628.

(6) Nonat, A. M.; Quinn, S. J.; Gunnlaugsson, T. Mixed f-d coordination complexes as dual visible- and near-infrared-emitting probes for targeting DNA. Inorg. Chem. 2009, 48, 4646-4648.

(7) Ryan, G. J.; Quinn, S.; Gunnlaugsson, T. Highly Effective DNA photocleavage by novel "rigid" $\mathrm{Ru}(\mathrm{bpy}) 3$-4-nitro- and -4-amino-1,8naphthalimide conjugates. Inorg. Chem. 2008, 47, 401-403.

(8) Zeglis, B. M.; Pierre, V. C.; Barton, J. K. Metallo-intercalators and metallo-insertors. Chem. Commun. (Cambridge, U. K.) 2007, 45654579.

(9) Moucheron, C.; Kirsch-De Mesmaeker, A.; Kelly, J. M. Photoreactions of ruthenium(II) and osmium(II) complexes with deoxyribonucleic acid (DNA). J. Photochem. Photobiol., B 1997, 40, 91-106.

(10) Erkkila, K. E.; Odom, D. T.; Barton, J. K. Recognition and reaction of metallointercalators with DNA. Chem. Rev. 1999, 99, 2777-2795

(11) Song, H.; Kaiser, J. T.; Barton, J. K. Crystal structure of Delta$[\mathrm{Ru}(\mathrm{bpy})(2) \mathrm{dppz}](2+)$ bound to mismatched DNA reveals side-byside metalloinsertion and intercalation. Nat. Chem. 2012, 4, 615-620.

(12) Gill, M. R.; Thomas, J. A. Ruthenium(II) polypyridyl complexes and DNA-from structural probes to cellular imaging and therapeutics. Chem. Soc. Rev. 2012, 41, 3179-3192.

(13) Elmes, R. B.; Orange, K. N.; Cloonan, S. M.; Williams, D. C.; Gunnlaugsson, T. Luminescent ruthenium(II) polypyridyl functionalized gold nanoparticles; their DNA binding abilities and application as cellular imaging agents. J. Am. Chem. Soc. 2011, 133, 15862-15865.

(14) Elmes, R. B.; Erby, M.; Bright, S. A.; Williams, D. C.; Gunnlaugsson, T. Photophysical and biological investigation of novel luminescent $\mathrm{Ru}(\mathrm{II})$-polypyridyl-1,8-naphthalimide Troger's bases as cellular imaging agents. Chem. Commun. (Cambridge, U. K.) 2012, 48, $2588-2590$.

(15) Kelly, J. M.; McConnell, D. J.; Ohuigin, C.; Tossi, A. B.; KirschDe Mesmaeker, A.; Masschelein, A.; Nasielski, J. Ruthenium polypyridyl complexes-their interaction with DNA and their role as sensitizers for its photocleavage. J. Chem. Soc., Chem. Commun. 1987, 1821-1823.

(16) Elias, B.; Creely, C.; Doorley, G. W.; Feeney, M. M.; Moucheron, C.; Kirsch-De Mesmaeker, A.; Dyer, J.; Grills, D. C.; George, M. W.; Matousek, P.; Parker, A. W.; Towrie, M.; Kelly, J. M. Photooxidation of guanine by a ruthenium dipyridophenazine complex intercalated in a double-stranded polynucleotide monitored directly by picosecond visible and infrared transient absorption spectroscopy. Chemistry 2007, 14, 369-375.

(17) Herman, L.; Ghosh, S.; Defrancq, E.; Kirsch-De Mesmaekera, A. $\mathrm{Ru}$ (II) complexes and light: molecular tools for biomolecules. J. Phys. Org. Chem. 2008, 21, 670-681.

(18) Puckett, C. A.; Barton, J. K. Methods to explore cellular uptake of ruthenium complexes. J. Am. Chem. Soc. 2007, 129, 46-47. 
(19) Allison, R. R.; Bagnato, V. S.; Sibata, C. H. Future of oncologic photodynamic therapy. Future Oncol. 2010, 6, 929-940.

(20) O'Connor, A. E.; Gallagher, W. M.; Byrne, A. T. Porphyrin and nonporphyrin photosensitizers in oncology: preclinical and clinical advances in photodynamic therapy. Photochem. Photobiol. 2009, 85, 1053-1074.

(21) Triesscheijn, M.; Baas, P.; Schellens, J. H. M.; Stewart, F. A. Photodynamic therapy in oncology. Oncologist 2006, 11, 1034-1044.

(22) Keane, P. M.; Poynton, P. E.; Hall, J. P.; Clark, I. P.; Sazanovich, I. V.; Towrie, M.; Gunnlaugsson, T.; Quinn, S. J.; Cardin, C. J.; Kelly, J. M. Enantiomeric conformation controls rate and yield of photoinduced electron transfer in DNA sensitized by $\mathrm{Ru}(\mathrm{II})$ dipyridophenazine complexes. J. Phys. Chem. Lett. 2015, 6, 734-738.

(23) Ortmans, I.; Elias, B.; Kelly, J. M.; Moucheron, C.; Kirsch-De Mesmaeker, A. $\left[\mathrm{Ru}(\mathrm{TAP})_{2}(\mathrm{dppz})\right]^{2+}$ : a DNA intercalating complex, which luminesces strongly in water and undergoes photo-induced proton-coupled electron transfer with guanosine-5'-monophosphate. Dalton Trans. 2004, 4, 668-676.

(24) Sheldrick, G. M. SHELXL-2013; 2013.

(25) Dickerson, M.; Sun, Y.; Howerton, B.; Glazer, E. C. Modifying charge and hydrophilicity of simple $\mathrm{Ru}(\mathrm{II})$ polypyridyl complexes radically alters biological activities: old complexes, surprising new tricks. Inorg. Chem. 2014, 53, 10370-10377.

(26) Gill, M. R.; Garcia-Lara, J.; Foster, S. J.; Smythe, C.; Battaglia, G.; Thomas, J. A. A ruthenium(II) polypyridyl complex for direct imaging of DNA structure in living cells. Nat. Chem. 2009, 1, 662667.

(27) Cosgrave, L.; Devocelle, M.; Forster, R. J.; Keyes, T. E. Multimodal cell imaging by ruthenium polypyridyl labelled cell penetrating peptides. Chem. Commun. (Cambridge, U. K.) 2010, 46, 103-105.

(28) Puckett, C. A.; Barton, J. K. Targeting a ruthenium complex to the nucleus with short peptides. Bioorg. Med. Chem. 2010, 18, 35643569.

(29) Puckett, C. A.; Barton, J. K. Fluorescein redirects a rutheniumoctaarginine conjugate to the nucleus. J. Am. Chem. Soc. 2009, 131, $8738-8739$.

(30) Abrams, M. J. Novel water soluble agents for photodynamic cancer therapy. Platinum Met. Rev. 1995, 39, 14-18.

(31) Elmes, R. B.; Erby, M.; Cloonan, S. M.; Quinn, S. J.; Williams, D. C.; Gunnlaugsson, T. Quaternarized pdppz: synthesis, DNAbinding and biological studies of a novel dppz derivative that causes cellular death upon light irradiation. Chem. Commun. (Cambridge, $U$. K.) 2011, 47, 686-688.

(32) Jacquet, L.; Davies, R. J. H.; Kirsch-De Mesmaeker, A.; Kelly, J. M. Photoaddition of $\mathrm{Ru}(\mathrm{tap})_{2}(\mathrm{bpy})^{2+}$ to DNA: a new mode of covalent attachment of metal complexes to duplex DNA. J. Am. Chem. Soc. 1997, 119, 11763-11768.

(33) Feeney, M. M.; Kelly, J. M.; Tossi, A. B.; Kirsch-De Mesmaeker, A.; Lecomte, J. P. Photoaddition of ruthenium(II)-Tris-1,4,5,8tetraazaphenanthrene to DNA and mononucleotides. J. Photochem. Photobiol., B 1994, 23, 69-78.

(34) Nasielski-Hinkens, R.; Benedek-Vamos, M.; Maetens, D. Synthesis of 9-substituted 1,4,5,8 tetraazaphenanthrenes. J. Heterocycl. Chem. 1980, 17, 873-876.

(35) Calucci, L.; Pampaloni, G.; Pinzino, C.; Prescimone, A. Transition metal derivatives of 1,10-phenanthroline-5,6-dione: Controlled growth of coordination polynuclear derivatives. Inorg. Chim. Acta 2006, 359, 3911-3920.

(36) Rau, S.; Schäfer, B.; Grüßing, A.; Schebesta, S.; Lamm, K.; Vieth, J.; Görls, H.; Walther, D.; Rudolph, M.; Grummt, U. W.; Birkner, E. Efficient synthesis of ruthenium complexes of the type (R-bpy) $2 \mathrm{RuCl} 2$ and $[(\mathrm{R}-\mathrm{bpy}) 2 \mathrm{Ru}(\mathrm{L}-\mathrm{L})] \mathrm{Cl} 2$ by microwave-activated reactions ( $\mathrm{R}: \mathrm{H}$, $\mathrm{Me}$, tert-But) (L-L: substituted bibenzimidazoles, bipyrimidine, and phenanthroline). Inorg. Chim. Acta 2004, 357, 4496-4503.

(37) Carter, M. T.; Rodriguez, M.; Bard, A. J. Voltammetric studies of the interaction of metal chelates with DNA. 2. Tris-chelated complexes of cobalt(III) and iron(II) with 1,10-phenanthroline and 2,2'bipyridine. J. Am. Chem. Soc. 1989, 111, 8901-8911.
(38) Lecomte, J. P.; Kirsch-De Mesmaeker, A.; Feeney, M. M.; Kelly, J. M. Ruthenium(II) complexes with 1,4,5,8,9,12-hexaazatriphenylene and 1,4,5,8-tetraazaphenanthrene ligands: key role played by the photoelectron transfer in DNA cleavage and adduct formation. Inorg. Chem. 1995, 34, 6481-6491.

(39) Chen, T.; Liu, Y.; Zheng, W. J.; Liu, J.; Wong, Y. S. Ruthenium polypyridyl complexes that induce mitochondria-mediated apoptosis in cancer cells. Inorg. Chem. 2010, 49, 6366-6368.

(40) Vollano, J. F.; Bossard, G. E.; Martellucci, S. A.; Darkes, M. C.; Abrams, M. J.; Brooks, R. C. The synthesis and in vitro photodynamic activity of a series of novel ruthenium(II)-2,3-naphthalocyanines. J. Photochem. Photobiol., B 1997, 37, 230-235.

(41) Gallagher, W. M.; Allen, L. T.; O’Shea, C.; Kenna, T.; Hall, M.; Gorman, A.; Killoran, J.; O'Shea, D. F. A potent nonporphyrin class of photodynamic therapeutic agent: cellular localisation, cytotoxic potential and influence of hypoxia. Br. J. Cancer 2005, 92, 1702-1710.

(42) Byrne, A. T.; O’Connor, A. E.; Hall, M.; Murtagh, J.; O’Neill, K.; Curran, K. M.; Mongrain, K.; Rousseau, J. A.; Lecomte, R.; McGee, S.; Callanan, J. J.; O'Shea, D. F.; Gallagher, W. M. Vascular-targeted photodynamic therapy with $\mathrm{BF} 2$-chelated tetraaryl-azadipyrromethene agents: a multi-modality molecular imaging approach to therapeutic assessment. Br. J. Cancer 2009, 101, 1565-1573.

(43) Gauthier, N.; De Winter, J.; Gerbaux, P.; Moucheron, C.; Luhmer, M.; Kirsch-De Mesmaeker, A. A Ru(II)-TAP complex, photoreagent for tryptophan-containing peptides: structure of the covalent photoadduct. Inorg. Chem. 2010, 49, 6796-6798.

(44) Rickling, S.; Ghisdavu, L.; Pierard, F.; Gerbaux, P.; Surin, M.; Murat, P.; Defrancq, E.; Moucheron, C.; Kirsch-De Mesmaeker, A. A rigid dinuclear ruthenium(II) complex as an efficient photoactive agent for bridging two guanine bases of a duplex or quadruplex oligonucleotide. Chemistry 2010, 16, 3951-3961.

(45) Zhang, J.; Wong, K. L.; Wong, W. K.; Mak, N. K.; Kwong, D. W.; HL, T. Two-photon induced luminescence, singlet oxygen generation, cellular uptake and photocytotoxic properties of amphiphilic $\mathrm{Ru}(\mathrm{II})$ polypyridyl-porphyrin conjugates as potential bifunctional photodynamic therapeutic agents. Org. Biomol. Chem. 2011, 9, 6004-6010.

(46) Poon, C. T.; Chan, P. S.; Man, C.; Jiang, F. L.; Wong, R. N.; Mak, N. K.; Kwong, D. W.; Tsao, S. W.; WK, W. An amphiphilic ruthenium(II)-polypyridyl appended porphyrin as potential bifunctional two-photon tumor-imaging and photodynamic therapeutic agent. J. Inorg. Biochem. 2010, 104, 62-70.

(47) Xu, W.; Zuo, J.; Wang, L.; Jia, L.; Chao, H. Dinuclear ruthenium(II) polypyridyl complexes as single and two-photon luminescence cellular imaging probes. Chem. Commun. 2014, 50, $2123-2125$

(48) Cetinbas, N.; Webb, M. I.; Dubland, J. A.; Walsby, C. J. Serumprotein interactions with anticancer $\mathrm{Ru}(\mathrm{III})$ complexes KP1019 and KP418 characterized by EPR. J. Biol. Inorg. Chem. 2010, 15, 131-145.

(49) Levina, A.; Mitra, A.; P.A, L. Recent developments in ruthenium anticancer drugs. Metallomics 2009, 1, 458-470.

(50) Pernot, M.; Bastogne, T.; Barry, N. P.; Therrien, B.; Koellensperger, G.; Hann, S.; Reshetov, V.; Barberi-Heyob, M. Systems biology approach for in vivo photodynamic therapy optimization of ruthenium-porphyrin compounds. J. Photochem. Photobiol., B 2012, 117, 80-89.

(51) Puckett, C. A.; Barton, J. K. Mechanism of cellular uptake of a ruthenium polypyridyl complex. Biochemistry. 2008, 47, 11711-11716.

(52) Youle, R. J.; Narendra, D. P. Mechanisms of mitophagy. Nat. Rev. Mol. Cell Biol. 2011, 12, 9-14.

(53) Cloonan, S. M.; Williams, D. C. The antidepressants maprotiline and fluoxetine induce type II autophagic cell death in drug-resistant Burkitt's lymphoma. Int. J. Cancer. 2011, 128, 1712-1723.

(54) Moucheron, C.; Kirsch-De Mesmaeker, A.; Choua, S. Photophysics of $\mathrm{Ru}$ (phen $)_{2}(\text { PHEHAT })^{2+}$ : a novel light switch for DNA and photo-oxidant for mononucleotides. Inorg. Chem. 1997, 36, 584-592.

(55) Hiort, C.; Lincoln, P.; Norden, B. DNA binding of $\Delta$ - and $\Lambda$ $\left[\mathrm{Ru}(\text { phen })_{2} \mathrm{DPPZ}\right]^{2+}$. J. Am. Chem. Soc. 1993, 115, 3448-3454. 
(56) The initial addition of st-DNA $(P / D$ of $0-4)$ resulted in an immediate fluorescence increase; however, upon further addition of stDNA $(P / D$ of $0-20)$ the emission spectrum of 4 exhibited a decrease in photoluminescence with no changes being observed thereafter. We attribute this behavior to biphasic interactions in which these bulky complexes are initially efficiently packed along the DNA helix, providing increased shelter from solvent quenching resulting in increased fluorescence compared to the isolated complexes along the helix. This is similar behavior that has been seen for related systems. $^{54,55}$ Similar behavior is observed with DNA homopolymers; however, the initial fluorescence intensity is increased upon interaction with $[\operatorname{poly}(\mathrm{dA}-\mathrm{dT})]_{2}$.

(57) Further titrations using the homopolymers $[\operatorname{poly}(\mathrm{dA}-\mathrm{dT})]_{2}$ and $[\text { poly }(\mathrm{dG}-\mathrm{dC})]_{2}$ revealed that significant discrimination was observed for both complexes, whereby 4 showed superior binding affinity with $K$ $=1.8 \times 10^{7} \mathrm{M}^{-1}( \pm 0.4)$ and $n=1.71( \pm 0.02)$ for $[\text { poly }(\mathrm{dA}-\mathrm{dT})]_{2}$ and $K=8.0 \times 10^{6} \mathrm{M}^{-1}( \pm 0.4)$ and $n=1.54( \pm 0.08)$ for $[\text { poly }(\mathrm{dG}-\mathrm{dC})]_{2}$. Similarly, 5 bound $[\text { poly }(\mathrm{dA}-\mathrm{dT})]_{2}$ with $K=1.1 \times 10^{7} \mathrm{M}^{-1}( \pm 0.17)$ and $n=1.85( \pm 0.02)$, while the binding of 5 to $[\text { poly }(\mathrm{dG}-\mathrm{dC})]_{2}$ gave $K=3.77 \times 10^{6} \mathrm{M}^{-1}( \pm 0.2)$ and $n=1.33( \pm 0.01)$. A full table of binding constants and binding site stoichiometries is available in Supporting Information. 